\title{
BetWeEN EAST AND WeSt. The INFLUENCE OF THE CULTS OF SAINTS ON PERSONAL NAME-GIVING IN MEDIEVAL HUNGARY
}

\author{
Mariann SLÍz \\ Eötvös Loránd University, Budapest, Hungary
}

\begin{abstract}
Conversion to Christianity caused great changes in the medieval Hungarian given name stock. As giving names after saints became one of the most significant motivations of naming, newly adopted Christian names gradually spread throughout the population and became exclusive by the $16^{\text {th }}$ century. The paper - drawing upon a $13^{\text {th }}-14^{\text {th }}$-century corpus of given names - introduces some phenomena which may have had a positive or negative effect on the popularity of a saint's name (cultural influence, support of a religious order or a dynasty, more than one saint with the same name, the overshadowing effect of newer or more supported cults, the novelty of a name).
\end{abstract}

Keywords: saints' cults, given names, medieval Hungary, chivalric culture.

\section{Aims and scopes}

It is common knowledge in onomastics that the cults of saints may influence name-giving. This impact can be detected in almost every category of proper names, but one of its most typical fields is personal name-giving. Choosing names for children after saints has been a characteristic way of naming in Hungary since the spread of Christiantity, although its importance dropped significantly in the past century. In the following, I will concentrate on the first period of this type of personal name-giving, the Middle Ages, as studying the personal name stock of this era offers several opportunities to detect the connections between the rise or even the decline of cults and the frequency of personal names. Such a study is possible due to the religious, cultural, and historical specifics of the period, on the one hand, and the databases containing a relatively large number of personal names from $11^{\text {th }}-15^{\text {th }}$-century Hungary, on the other. I will rely upon these databases and name dictionaries, especially on the Dictionary of Personal Names from the Age of the Árpáds (Fehértói 2004), on my own corpus from the $14^{\text {th }}$ century (Slíz 2011, 2017), and on János N. Fodor's database from the $15^{\text {th }}-16^{\text {th }}$ centuries (Fodor 2010a). Examples from this era will serve two purposes: firstly, to demonstrate the connections between the cults of saints and personal name-giving in medieval Hungary and, secondly, to bring the methodological difficulties and possibilities of such a survey to light. 


\section{The structure of the medieval given name stock and its changes in Hungary}

To successfully evaluate the evidence of anthroponyms, it is essential to understand the structure of the given name stock and its changes in medieval Hungary. Its base layer was, of course, represented by names of Hungarian origin. However, names of foreign origin have always been a part of the given name stock, too. Of these, the oldest group that can still be detected comprises names of Turkic origin. After the Hungarian settlement in the Carpathian Basin, names of Slavic and German origin also began to enter the given name stock, and some names of French origin were borrowed during the $12^{\text {th }}-14^{\text {th }}$ centuries. This part of the name stock (half of them Hungarian and half foreign) may be referred to as secular names, since they were not connected to the Church. The elements of the other part of the personal name stock were given according to Christian naming practices, following the spread of Christianity in Hungary from the $11^{\text {th }}$ century onwards. The sources of the names were the Holy Bible and martyrologies containing names of saints. These names were mostly taken from Greek or Latin, although names originating from other languages could also enter this category along with the canonization of their bearers. For instance, the name László 'Ladislaus' is of Slavic origin, but this secular name was recategorized as a Christian name due to the canonization of King Ladislaus I at the end of the $12^{\text {th }}$ century.

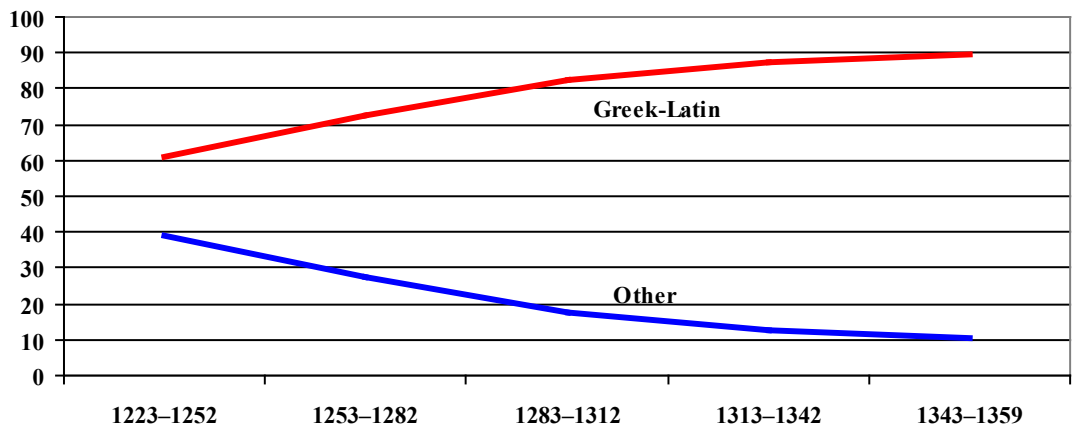

Figure 1: Changes in the ratio of the two main groups of names in the $13^{\text {th }}-14^{\text {th }}$ centuries (based on the corpus of Slíz 2011, 2017)

Knowledge regarding the change in the frequency of these groups is still rather fragmental. As no database is available for a more complex study, all that can be said is that Christian names spread gradually in the $11^{\text {th }}-12^{\text {th }}$ centuries in all social classes. However, the picture is clearer in the following two or three centuries. The diagram below, which is based on my corpus of $13^{\text {th }}-14^{\text {th }}$-century given names, shows that the use of names of Greek-Latin origin (i.e. the majority of Christian names) had run to $60 \%$ by the 1220 s and reached $90 \%$ by the middle of the $14^{\text {th }}$ century (cf. Figure 1). This means that secular names, independently of their Hungarian or foreign origin, were crowded out of the personal name stock by the $15^{\text {th }}-16^{\text {th }}$ centuries. The 
homogenization of the given name stock led to a great rise in the average frequency of names: while a name was borne by two people on average in the first part of the $13^{\text {th }}$ century, this number increased to 14 by the middle of the $14^{\text {th }}$ century. This change must be kept in mind when examining the influence of cults on name-giving, as it provides a device to decide whether the increase in the frequency of a name was due only to the tendential rise in the average frequency of names within the given name stock, or was the result of the impact of the name-bearing saint's cult.

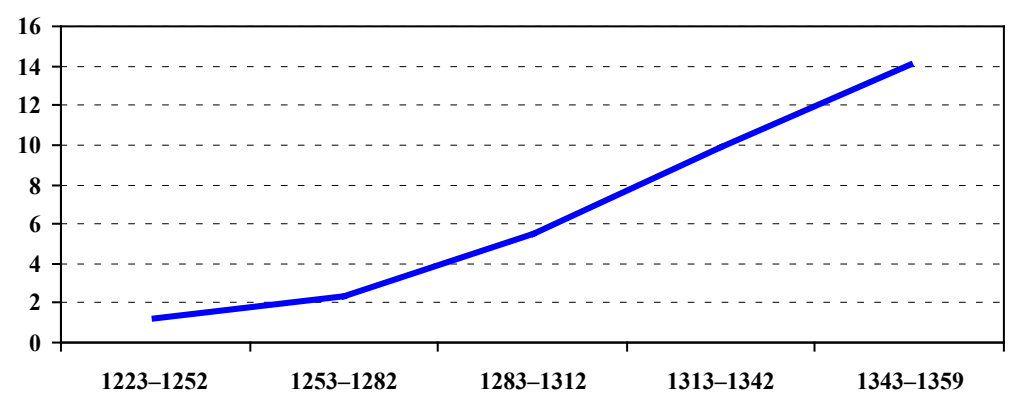

Figure 2: The change of the average frequency of names in the $13^{\text {th }}$ $14^{\text {th }}$ centuries (based on the corpus of Slíz 2011, 2017)

\section{Cults of saints and personal name-giving}

Hungary was the target of the evangelizing activity of both Christian Churches for centuries. Therefore, the cults of saints which affected name-giving in medieval Hungary can be grouped into three types: Eastern, Western, and domestic. However, the borders of these categories are quite fuzzy: several cults can be listed in more than one category. For example, Saint Martin of Tours was a Western saint, but was also regarded as a domestic saint in Hungary due to his Pannonian origin. As a contrary example, Elizabeth of the House of Árpád, Countess of Thuringia, became a highly venerated saint not only in Hungary but in the whole Catholic world and is considered a domestic saint in Germany. Moreover, the very concept of 'saint' is fuzzy as well. The veneration of Saint Margaret of Hungary is a good example of this phenomenon: she had been highly respected as a domestic saint all over Hungary since the day of her death in spite of the fact that the recurring efforts for her canonization only succeeded in 1943.

The strength of a cult may change over time and may bear territorial or social differences, too. The popularity of saints' names usually reflects these changes and alterations. However, a direct proportion between the popularity of the cult of a saint and the frequency of their name cannot always be revealed, as religious motives were never the only reason for choosing a saint's name for a child. Other motivations, such as the inheritance of names, the day of birth, or the parents' tastes should also be taken into consideration. Thus, it can never be irrevocably stated that the increase or decline 
in the frequency of a name was due to parallel changes in the popularity of the saint. Nevertheless, several pieces of data can be found which provide fairly reliable evidence for the influence of cults on personal name-giving. In the following, I will introduce some examples to demonstrate the factors which may have a positive or negative impact on the popularity of a saint's name.

\section{Phenomena which may have had a positive impact on the popularity of a saint's name}

\section{The adoption of a cult supported by a religious order}

To start with positive factors, the adoption and the spread of a cult have to be mentioned first and foremost. These phenomena can be demonstrated best by referring to the increasing popularity of the name Domonkos 'Dominic' in the $13^{\text {th }}$ century. Although the earliest known mention of this name in Hungary dates back to the very beginning of the $11^{\text {th }}$ century (Fehértói 2004: 255), the name was not among the 12 most fashionable ones in the $11^{\text {th }}-12^{\text {th }}$ centuries (Fehértói 1997: 73). However, there is no other piece of information regarding its frequency. A more detailed picture can be outlined from the following two centuries. The diagram, which is based on the previously mentioned corpus of the author of this paper, shows a steady increase in the popularity of the name Domokos in the $13^{\text {th }}$ century, and a slightly more moderate rise in the first decade of the $14^{\text {th }}$. This cannot be explained by the common increase of the average frequency of names alone, as the name also became more fashionable in the period, jumping from the $14^{\text {th }}$ to the $11^{\text {th }}$ place on the list of the most fashionable names. This change must have been promoted by the canonization of Dominic of Guzmán, the founder of the Dominican order, in 1234 and was fostered by the Dominicans, who settled in Hungary after 1221 and expanded throughout the country at a considerably fast pace (Zágorhidi Czigány 2015: 27-28).

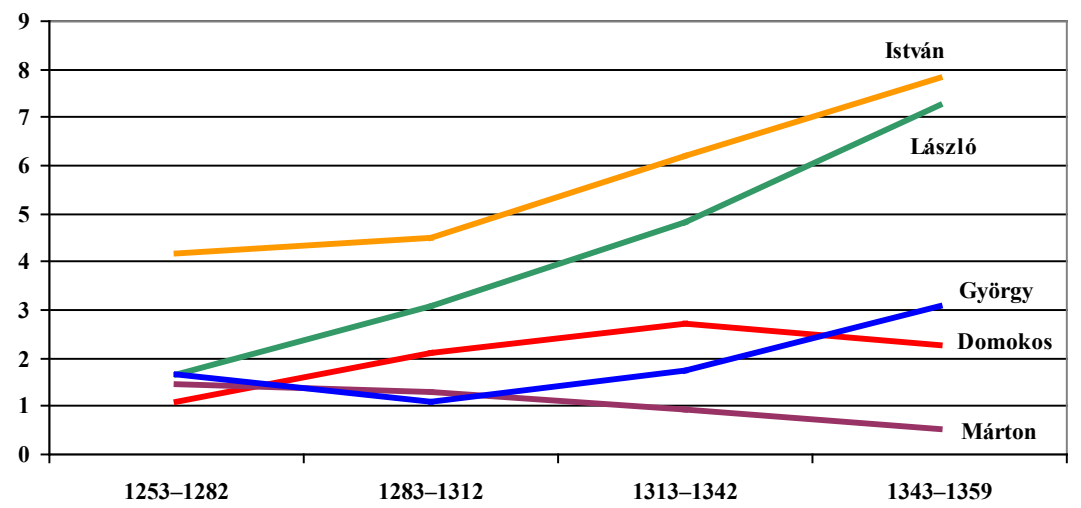

Figure 3: Changes in the frequency of the names István, László, György, Domokos, and Márton in the $13^{\text {th }}-14^{\text {th }}$ centuries (based on the corpus of Slíz 2011,2017) 


\section{Royal support}

As has already been shown, the spread of a cult and of the corresponding saint's name may have been promoted by a religious order. Similarly, royal support could have also had a positive impact on the popularity of a saint's name. The best examples of this phenomenon are the names of the saint kings of the Árpáds: István 'Stephen' and László 'Ladislaus'. Family saints always had a special importance to dynasties, as they emphasized their international significance and inland legitimacy. Their importance increased drastically when a new dynasty took the throne in a country. This was the case when King Charles I obtained the crown of the Hungarian Kingdom: to gain the support of the Hungarian church and nobility, he needed to emphasize his matrilineal descendance from the extinct ruling dynasty, the House of Árpád (cf. Klaniczay 1986). Supporting the cults of the Hungarian saint kings was a suitable device in his efforts. To indicate his support, he named two of his sons István 'Stephen' and László 'Ladislaus'. A codex called Hungarian Anjou Legendary (Levárdy ed. 1973), which was presumably made for Prince Andrew, another son of King Charles I, narrates the life of Saint Ladislaus in 24 pictures. This number is larger than in the case of any other saint, except for James the Greater, the four apostles and, of course, Christ. The son and successor of King Charles, Louis I, proceeded to promote the cults of the saint kings, especially Saint Ladislaus, who became the patron saint of the royal family. Ladislaus' portrait decorated the golden forints of Louis I (Klaniczay 1986: 69-70), numerous chapels were named after him in the period (Mezö 1996: 139), and his character played an important role in the "Deeds" of the Nameless Minor composed at Louis's court as the helper of the Hungarians against the Tatars in 1345 (Engel-Kristó-Kubinyi 1998: 114). As a result, the popularity of the two saint kings' names rose significantly among the noble class during the $14^{\text {th }}$ century, as can be seen in the diagram.

\section{More saints with the same name}

When a name was borne by more than one saint venerated at the same time, in the same place, it naturally had greater chance to become frequent. This phenomenon is also demonstrated by the diagram: although the increase in the popularity of the name László is steeper, István remained more frequent during the $13^{\text {th }}-14^{\text {th }}$ centuries. This was due to two factors: firstly, the veneration of Saint Stephen, the first King of Hungary (since 1083), had started more than a century before the country-wide cult of Saint Ladislaus (which began in 1192); secondly, in addition to the king there was another saint who bore the name István, the first martyr of the Church. The outstanding popularity of the female names Erzsébet 'Elizabeth' and Margit 'Margaret' was also due to more than one saint. The name of John the Baptist's mother was fashionable all over Europe, and the veneration of Saint Elizabeth of Hungary from the $13^{\text {th }}$ century onwards established the name as the most popular in medieval Hungary (cf. Berrár 1952, Hajdú 1988: 62). The second most frequent female name in medieval Hungary was Margit among all social classes, due to the veneration of Saint Margaret of Antioch 
and the unofficial cult of Princess Margaret, daughter of Béla IV. The popularity of Saint Margaret of Antioch began to increase at the end of the $12^{\text {th }}$ century, thanks to Queen Agnes of Antioch and the idea of a crusade, which appeared at the court of King Béla III. This influence was enhanced by the fact that King Andrew II brought a relic of the saint from his crusade in 1217 (Koszta 2006). Knowing this, it is not a surprise that the first Margaret in the House of Árpád was the daughter of Béla III and Queen Agnes. Moreover, two other princesses were named after the saint: the elder and the younger Margaret, daughters of Béla IV. The efforts for the canonization of the younger Margaret of Hungary started right after her death, in 1271, and were repeated in 1276, then restarted by King Charles I in 1306. This religious action was a part of his endeavor to confirm his claim to the Hungarian throne by his saintly kinship (cf. Klaniczay 1986: 68). These cases lead to a methodological problem for onomasticians, as there is no chance of dividing the influence of the saints in question on the frequency of their names.

\section{Cultural influences}

Cultural influences may have also had a positive impact on the frequency of a saint's name. This is demonstrated by the names of military saints. Amongst them, the most significant ones in medieval Hungary were, beyond question, Saint George and Saint Ladislaus, especially during the blossoming of chivalric culture. As for Saint Ladislaus, his cult was promoted by Louis I not only because of their kinship, but also because the knight saint served as a role model for the knight king. Consequently, the popularity of the cult and name was amplified by several factors. It is no wonder that the name László was more fashionable among the nobility (according to the corpus of Slíz 2011 and 2017), since this class was most influenced by chivalric culture and the ideals of the royal court.

The veneration of Saint George began in the $11^{\text {th }}$ century in Hungary, two centuries before the cult of Saint Ladislaus (Mezö 1996: 84). The cult of this Eastern saint was boosted by the crusades and chivalric ideas, but the peak of this veneration was also under the reign of the Angevin kings in the $14^{\text {th }}$ century (cf. e.g. Gulyás 1997, Magyar 2006). King Charles I named the chivalric order that he established after this saint, and several reliefs and pictures along with the famous sculpture by the Kolozsvári brothers bear witness to the popularity of the military saint in the second half of the $14^{\text {th }}$ century. The frequency of the name György followed the changes of the cult, as can be seen in the diagram (Figure 3). It was not among the first 12 male names at the beginning of the $14^{\text {th }}$ century, when its popularity started to rise relatively quickly. Nevertheless, it reached the $3^{\text {rd }}$ position by the beginning of the $15^{\text {th }}$ century, according to the databases of Katalin Fehértói (1968: 321) and János N. Fodor (2010b: 126). 


\section{Phenomena which may have had a negative impact on the popularity of a saint's name}

\section{The overshadowing effect of newer or more supported cults}

Turning now to obstructing factors, the overshadowing effect of newer or more supported cults should be mentioned first. A perfect example of this phenomenon is the fading popularity of Márton 'Martin' in the $14^{\text {th }}$ century. The cult of Saint Martin of Tours in the Carpathian basin can be traced to before the Hungarian settlement. It was adopted early by the Hungarian Church and the royal court, and he became the patron saint of the Arpad dynasty and the country. Due to this, the first known instance of the name Márton in Hungary is fairly early (1014; Fehértói 2004: 522), and it is the $7^{\text {th }}$ most frequent name in the corpus of the $11^{\text {th }}-13^{\text {th }}$ centuries (Fehértói 1997: 73). However, its popularity dropped from the second part of the $13^{\text {th }}$ century onwards, as shown in Figure 3. While it held the $12^{\text {th }}$ position at the time, it dropped from the 15 most frequent names by the middle of the $14^{\text {th }}$ century, and was only the $20^{\text {th }}-24^{\text {th }}$ in the $15^{\text {th }}-16^{\text {th }}$-century corpus of János N. Fodor (2010b: 126-131). This decline can be accounted for by how the cult and the name had become traditional and usual by the $13^{\text {th }}$ century. Newly embraced cults and the stronger royal support of other saints pushed it into the shadows. Additionally, the $14^{\text {th }}-15^{\text {th }}$-century crisis of the Benedictine order, the greatest supporter of the cult of Saint Martin, interwoven with the upsurge of the Dominicans and the name Domokos may have played a significant role in the downturn of the name.

\section{The novelty of a name}

When a name was brand new in the name stock, its spread may have come against a difficulty despite the support of a religious order or a dynasty. This happened in the case of the name Lajos 'Louis'. Regardless of how hard King Charles I endeavored to introduce the cult of his Neapolitan uncle, Saint Louis of Toulouse, to Hungary (Dümmerth 1982: 271, 310; Klaniczay 1986: 70-71), even naming one of his sons after him, Lajos remained a rare name until the end of the $18^{\text {th }}$ century (Hajdú 2003: $362-369,554-580)$. The cause of the unpopularity of the name must have been the relatively short rule of the dynasty in Hungary. The name of Saint Francis had a similar fate: although the Franciscan order spread in Hungary as quickly as the Dominicans, the name Ferenc was definitely rare in the $13^{\text {th }}-14^{\text {th }}$ centuries according to my corpus. The explanation lies in the fact that Ferenc became a given name only at the end of the $12^{\text {th }}$ century from the byname of Saint Francis.

\section{Conclusion}

Considering all of factors mentioned above, it is clear that the investigation of the influence of cults of saints on personal name-giving faces great challenges. The connection between the two is indisputable; the most fashionable names and cults can easily be listed. However, a more detailed survey which focuses on the changes of 
the frequency of names and seeks to discover the reasons behind these changes must face the problem that the actual motivation behind name-giving cannot be revealed on the basis of historical sources. Consequently, the effect of cults can be detected only in special cases - for example, in periods in which a cult spread or was supported by a religious order or a dynasty. Moreover, it is essential to accentuate that negative changes also deserve the attention of onomasticians, as these may also show correlation between cults and name-giving habits.

\section{References}

Berrár, J. 1952. Nói neveink 1400-ig [Hungarian female names until 1400]. A Magyar Nyelvtudományi Társaság Kiadványai 80. Budapest: Magyar Nyelvtudományi Társaság.

Dümmerth, D. 1982. Az Anjou-ház nyomában [In the wake of the Angevin dynasty]. Budapest: Panoráma.

Engel, P., Gy. Kristó and A. Kubinyi. 1998. Magyarország története 1302-1526 [The history of Hungary 1302-1526]. Budapest: Osiris Kiadó.

Fehértói, K. 1968. Egy XIV. századi nagybirtok jobbágyainak személynévanyaga [The personal name stock of serfs from a $14^{\text {th }}$-century latifundium]. Magyar Nyelv 64: 317-331.

Fehértói, K. 1997. Árpád-kori közszói eredetű személyneveinkről [On personal names derived from apellatives in the Arpadian age]. Magyar Nyelvör 121: 71-75.

Fehértói, K. 2004. Árpád-kori személynévtár (1000-1301) [Dictionary of personal names from the Arpadian age (1000-1301)]. Budapest: Akadémiai Kiadó.

Fodor, J.N. 2010a. A Felsö-Tisza-vidék késő középkori személyneveinek szótára (1401-1526) [Dictionary of medieval personal names in the Upper Tisza region]. Magyar Nyelvtudományi Értekezések 3. Budapest: ELTE Magyar Nyelvtudományi és Finnugor Intézet Magyar Nyelvtörténeti, Szociolingvisztikai, Dialektológiai Tanszéke.

Fodor,J.N. 2010b. Személynevek rendszere a kései ómagyar korban. A Felsö-Tisza-vidék személyneveinek nyelvi elemzése (1401-1526) [The system of personal names in the Late Old Hungarian Age. A linguistic analysis of personal names in the Upper Tisza region]. Magyar Névtani Értekezések 2. Budapest: ELTE BTK Magyar Nyelvtudományi és Finnugor Intézet.

Gulyás, É. 1997. Szent György középkori kultusza és legendája a néphagyományban [The medieval cult and legend of Saint George in Hungarian folklore]. Tisicum. A Jász-Nagykun-Szolnok Megyei Múzeumok Évkönyve 10: 187-205.

Hajdú, M. 1988. Adalék nőneveink korai divatjához [Data regarding the early fashion of female names in Hungary]. In Studia in honorem P. Fábián, E. Rácz, I. Szathmári oblata a collegis et discipulis, 61-65. Budapest: ELTE BTK Mai Magyar Nyelvi Tanszék.

Hajdú, M. 2003. Általános és magyar névtan. Személynevek [General and Hungarian onomastics. Personal names]. Budapest: Osiris Kiadó.

Klaniczay, G. 1986. Az Anjouk és a szent királyok. Fejezet a középkori szenttisztelet történetéből. [The Angevin dynasty and the saint kings. A chapter in the history of the medieval cults of saints]. In „Mert ezt Isten hagyta...” Tanulmányok a népi vallásosság köréból, G. Tüskés (ed.), 65-87. Budapest: Magvető Kiadó.

Koszta, L. 2006. Adalékok Antiochiai Szent Margit Árpád-kori tiszteletéhez [Data regarding the veneration of Saint Margaret of Antioch in the Arpadian age]. Acta Universitatis Szegediensis, Acta Historica 124: 23-28. 
Levárdy, F. (ed.) 1973. Magyar Anjou Legendárium [Hungarian Anjou Legendary]. Budapest: Magyar Helikon.

Magyar, Z. 2006. Szent György a magyar kultúrtörténetben. A Kárpát-medence Szent Györgyhagyományainak néprajzi és müvelődéstörténti rétege [Saint George in Hungarian cultural history. The ethnographic and cultural historical stratum of the Saint George tradition in the Carpathian basin]. Budapest: Kairosz Kiadó.

Mezö, A. 1996. A templomcím a magyar helységnevekben (11-15. század) [The names of patron saints of churches in Hungarian settlement names $\left(11^{\text {th }}-15^{\text {th }}\right.$ centuries $\left.)\right]$. METEM-könyvek 15. Budapest: Magyar Egyháztörténeti Enciklopédia Munkaközösség.

Slíz, M. 2011. Anjou-kori személynévtár (1301-1342) [Dictionary of personal names from the Angevin age (1301-1342)]. Budapest: Históriaantik.

Slíz, M. 2017. Anjou-kori személynévtár (1342-1359).) [Dictionary of personal names from the Angevin age (1342-1359)]. Budapest: Magyar Nyelvtudományi Társaság.

Zágorhidi Czigány, B. 2015. A domonkos rend megtelepedése Magyarországon [The settlement of the Dominican order in Hungary]. Tanítvány - A magyar domonkosok lapja 2015 (3): 27-35. 